\title{
Remorse in psychotic violent offenders: An overvalued idea?
}

\author{
Akshita Dandawate 1 \\ Natasha Kalebic 1 \\ Nicola Padfield 2 \\ Jackie Craissati 3 \\ Pamela J. Taylor 1
}

1 School of Medicine, Cardiff University, Cardiff, UK

2 Faculty of law, Fitzwilliam College, Cambridge, UK

3 Psychological Approaches Community Interest Company, UK

Correspondence

Pamela J. Taylor, School of Medicine, Division of Psychological Medicine and Clinical Neurosciences, Hadyn Ellis Building, Cardiff CF24 4HQ, UK

Email: taylorpj2@cardiff.ac.uk

Expressing remorse - or not - appears to influence criminal justice outcomes, but preliminary exploration of both judicial and psychological concepts suggests they lack clarity.

We asked the following questions: does psychosis impair capacity for, or expression of, remorse for a homicide or other serious harm to others? Is failure to express remorse for an offence associated with recidivism? We conducted systematic reviews of empirical literature on remorse for serious violence while psychotic, and on relationships between remorse and reoffending regardless of mental state. No articles on remorse for homicide or other serious violence while psychotic were identified.

There is weak evidence that lack of remorse is associated with reoffending generally, but nothing specific to psychosis. The literature is strong enough to support a case for research into valid measurement of remorse for offending, associations of such measures with recidivism, and whether a change in remorse can be effected - or matters. It is not strong enough to support reliance on perceptions of the presence or absence of remorse as a basis for judicial decisions.

\section{1 | I N T R O D U C T I O N}

Appearing remorseful after seriously harming another person may help in court. Failure to show remorse risks classification as 'evil' and deserving of the severest punishment. In psychiatric practice, both prominent remorse and apparent failure to express remorse could be construed as pathological. Lawyers and mental health practitioners come together when an alleged offender is brought before the courts - so what scientific evidence on remorse exists to support useful interactions between these professions in the assessment of psychosis and serious offending? 
Worldwide, the courts commonly consider evidence of remorse when judging criminal cases. In South Carolina, for example, remorse was the third most aggravating factor in capital cases (Zhong, 2015). van Oorschot, Mascini, and Weenink (2017) refer to the absolute centrality of remorse to judges' decision-making in Dutch courts. In England, an observational study of 52 sentencers, sentencing 162 defendants between them, found that, while judges took account of the immediate circumstances of the offence, the defendant's response to the offence was important. Within the list of mitigating factors that most affected outcome, intense remorse was only highly ranked (fourth); it was also, however, the third most likely category to produce inconsistent responses (Jacobson \& Hough, 2007). In Denmark, Johansen (2019) demonstrated the importance of judges' 'cultural understanding' in relation to the offender in determining what constitutes an 'appropriate' emotional response. Zhong et al. (2014), in a study with a quarter (32) of Connecticut's experienced judges (range 7-30 years of sitting), found that while each was able to describe his or her own system for deciding on the presence or absence of remorse, there was considerable inconsistency between them. The media and public also weigh remorse heavily when considering offenders (Bibas \& Bierschbach, 2004).

Research with experimental juror participants also indicates that their beliefs about a defendant's remorse and its mitigating value are linked to aspects of the crime, including its planning and 'viciousness', but their own characteristics also had some effect (Eisenberg, Garvey, \& Wells, 1997).

It is not surprising, then, that emphasis on remorse has been challenged in the literature (e.g. Bandes, 2018) and concern expressed about the lack of empirical underpinning of its use (Maslen, 2015; Padfield, 2013). Further, despite the weight placed on it, we could find no widely accepted legal definition, and no reliable and valid rating schedule. This may be partly because it is a complex concept that encompasses guilt, shame, regret, contrition and repentance (Proeve \& Tudor, 2010). Its indicators or components have immediate practical implications, such as a guilty plea saving justice resources, at least in the short term. It also has longer-term interactional consequences. The latter, through acceptance of expressions of regret, may ultimately lead to a restorative justice pathway, but there is a question of the genuineness of the offender's position. The German Federal Court of Justice, for example, argues that a confession and admission of guilt, revealing truth and acceptance of responsibility, will result in mitigation or sentencing discount only if they are accompanied by remorse, and are not a dominating, though understandable, motive to receive a more lenient punishment [Bundesgerichtshof(Federal Court of Justice) 4 StR 481/16 -Judgment from 2 February 2017]. Legal justification lies in a doctrine that has been applied outside as well as inside courts, e.g. the truth commissions in South Africa and Rwanda (GobodoMadikizela, 2015). Steps in the process seem to be as follows: I confess; I am truthful; I am responsible for what happened (guilty); I regret what I have done; I apologize to the victim(s); and I will not do it again. This last component seems to be behind the other key judicial reason for allowing remorse to affect sentencing - a remorseful person is perceived as needing less deterrence and less incapacitation as $s /$ he is less likely to reoffend (Zhong, 2015).

In the empirical psychological literature, there is some conflation of remorse with guilt, but there is growing evidence for separating guilt from a concept of shame. Tangney, Stuewig, 
and Hafez (2011), for example, argue that'most psychologists regard remorse as a primary component of the guilt experience'. Although they provide little evidence for this statement per se, they present a well evidenced argument for making a distinction between guilt and shame, the former a potentially constructive experience of taking responsibility for an action and the latter a position that is associated with avoidance of considering a state or act, which may actually inhibit its resolution. In relation to offending, this could increase risk of repetition. Tilghman-Osborne, Cole, and Felton (2010) consider that the literature supports 23 theory-based definitions of guilt and 25 measures of guilt, with a lack of conceptual convergence. The measures do not necessarily correspond to the definitions from which they are derived. These authors suggest, however, two main clusters of measures: one of trait-like characteristics, including sense of moral and social transgression - or lack of it - largely internalized and private to the person; and the other, they suggest, perhaps capturing traits but also event-specific behaviours, and which is more public. The latter would encompass activity, including developing feelings of responsibility, apology, and reparation, and remorse. In essence, painful feelings about transgressions of some kind not necessarily criminal - are, on the one hand, internalized as largely self-tormenting shame, with some avoidance or reality, and, on the other, displayed as a more public face of guilt which, in turn, has more practical, reparative value.

Capacities for remorse and empathy have been linked in the psychological literature, although sometimes with emphasis on the remorse of the offender generating empathy in the person offended against (Davis \& Gold, 2011). Empathy refers to the capacity to recognize, understand and feel the state of mind of another and to generate an appropriate response to those experiences. Empathy impairments have been evidenced among people with schizophrenia (e.g. Derntl et al., 2009), with a probable anatomical component in damage to frontotemporal regions of the brain (Derntl et al., 2012), particularly affecting 'perspective taking' and emotional responsiveness. Furthermore, the kind of cognitive distortion that is fundamental to a delusion may mean that, in this context, if a violent act is delusionally driven, far from taking the victim's perspective or even understanding that the person assaulted has become a victim, the action may seem entirely 'right'. According to Zhong et al. (2014), most judges do think that mental illness is likely to affect the relevance of remorse: "Your ability to be able to put yourself in someone else's shoes is clouded by your mental illness" or "mental illness 'almost neutralizes' remorse". Nevertheless, given evidence that impairments in empathy or components of it are associated with violence with psychosis (Bragado-Jiménez \& Taylor, 2012) or without it (Jolliffe \& Farrington, 2004), it may be argued that it could be useful to consider evidence on the nature and extent of remorse, at least when making decisions about release after a period of treatment, if not in court.

Our aims, therefore, were to examine evidence on remorse among people with delusions or wider evidence of psychosis after the most serious of crimes - homicide. Our research questions were: Is there evidence in already published literature that capacity for remorse or its expression after a homicide is impaired among people with psychosis? Is there evidence for change in remorse during the course of the illness and its treatment? To what extent is violent recidivism associated with failure to experience or express remorse and does this differ between people with and without psychosis? 


\section{METHODS}

Two separate systematic reviews were conducted - one for each research question - using the search databases Scopus, Psycinfo, Medline, Web of Science and Assia.

Terms for the first review were chosen not only for delusion, but also for psychosis more widely to ensure full capture of relevant material. To the term remorse, we added terms for presumed components or relevant processing skills. The final list of search terms was entered into the databases as follows, adjusting for syntax relevant to each database: ("Psychosis" OR "psychotic illness*" OR "schizo" OR "schizoaffective" OR "psychotic*" OR "delusion" OR "hallucination" OR "negative symptom") AND ("Remorse" OR "guilt" OR "shame" OR "repent" "empathy" OR "regret*"). For the second question about remorse and recidivism, as we wanted to be able to compare risk of recidivism in the context of remorse or its absence with and without delusions or psychosis, we excluded the psychosis terms. The following terms were used in the same databases, in a similar manner: ("Remorse" OR "guilt*" OR "shame*" OR "repent*" OR "empathy") AND ("reoffend" OR "recidivism" OR "relapse" OR "repeat crime" OR "revert*"). The final search algorithms for each database, with search results, are given in the Online Appendix 1 . The results were exported to ENDNOTE and duplicates were removed. Reference lists of each selected article were checked for further relevant material, and authors were contacted, where possible, about further work in the field. The following journals were hand-searched for the complete years 20132019: Behavioral Sciences and the Law; Cornell Law Review online; Criminal Behaviour and Mental Health; Journal of American Psychoanalytic Association; Medicine, Science and the Law; International Journal of Offender Therapy and Comparative Criminology; Criminal Justice and Behavior; Aggressive and Violent Behavior; Australian and New Zealand Journal of Criminology; Journal of Forensic Psychiatry and Psychology; Clinical Psychology Review; New York University Review of Law and Social Change; and The Journal of the American Academy of Psychiatry and the Law.

Articles were included in the first review only if a diagnosis of psychosis had been made and/or psychotic symptoms had been recorded according to a tested and recognized measure or system and reference had been made to remorse, guilt or shame in relation to a homicide or other seriously violent offence. Articles were excluded if the work had been done only with healthy people or only people with other diagnoses and there was either no reference to remorse or, where there was, it was confined to concerns about non-criminal matters (e.g. personal health or having a stillborn child) or was a long-standing trait. No diagnostic restrictions were imposed on the second review, but only studies that recorded remorse and/or sense of guilt for a specified index offence and had measured violent reoffending subsequently were included.

Selections for possible inclusion were made from the first 100 titles and abstracts by three of us (AD, NK, PJT), each blind to the other's selections. There was $98 \%$ agreement, so AD completed the rest of the selection alone. Data were then extracted from each selected article according to a purpose-designed checklist.

Meta-analysis was considered. 


\section{RESULTS}

Among 2823 potentially relevant, unique titles identified, there were no studies of remorse for a homicide or other seriously violent act among people with delusions, other psychotic symptoms or a diagnosis of schizophrenia or similar condition (see Figure 1 ). Several articles referred to guilt as a symptom of psychosis that worsened with the severity of the illness, but none evaluated this in relation to any specified and real act.

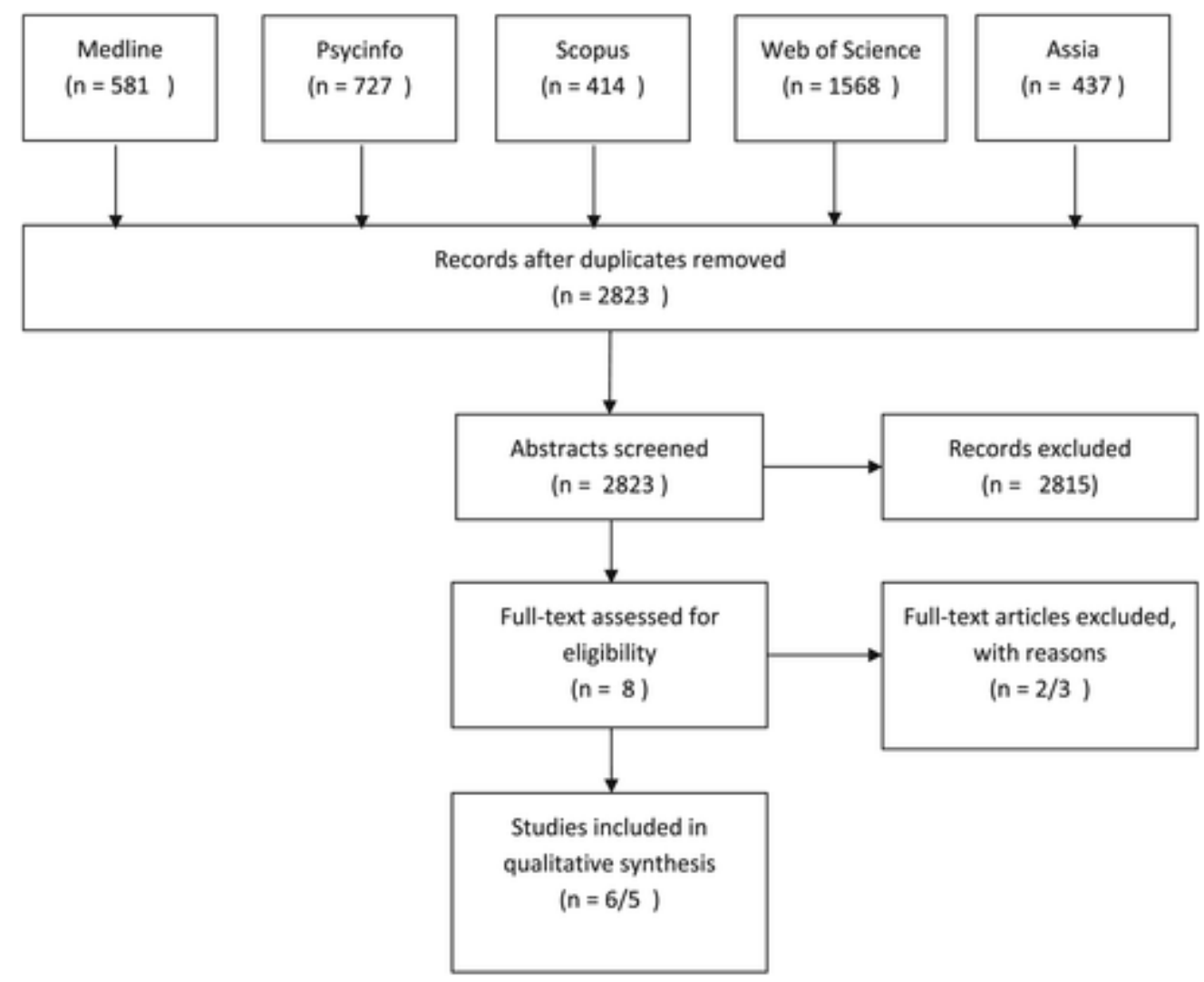

Figure 1

Prisma flow chart

Just two studies were identified that tested associations between remorse or guilt for a particular offence and subsequent recidivism, although neither did so among people with a psychotic illness (see Table 1). One was a substantial study of young men in prison in northern Germany, which found some association between feelings of guilt within a month of arriving in prison and desistence from further offending, even after allowing for other potentially relevant variables, and interaction between guilt and shame (Hosser et al., 2008). Slightly under half of these young men described experiencing guilt often, but the most striking finding was that the proportion experiencing such guilt reduced over time, even after allowing for sample attrition with release. Conversely, the less 'useful' sense of shame increased over time. A small Swedish study of male adolescents in residential settings failed to find a relationship overall between admission of the crime and feelings of guilt for it and subsequent recidivism (Holmqvist et al., 2009). There was, however, an intervention interaction effect between less initial consciousness of guilt and impact of an aggression replacement training intervention, with those young men with lower initial consciousness of guilt benefiting most. 
Table 1. Remorse and recidivism

\begin{tabular}{|c|c|c|c|c|c|c|}
\hline $\begin{array}{c}\text { Study } \\
\text { questions }\end{array}$ & Sample & Measures & Findings & $\begin{array}{l}\text { Authors' } \\
\text { conclusions }\end{array}$ & Comments & $\begin{array}{c}\text { Referenc } \\
\text { e, place }\end{array}$ \\
\hline \multirow[t]{2}{*}{$\begin{array}{l}\text { Are feelings } \\
\text { of shame } \\
\text { and guilt } \\
\text { during } \\
\text { imprisonme } \\
\text { nt related } \\
\text { to criminal } \\
\text { behaviour } \\
\text { after } \\
\text { release } \\
\text { from } \\
\text { prison? }\end{array}$} & $\begin{array}{l}1243 \\
\text { young } \\
\text { male } \\
\text { prisoner } \\
\text { s, mean } \\
\text { age } 21 \\
\text { (median } \\
20, \\
\text { range } \\
14-24 \text { ) } \\
\text { from six } \\
\text { northern } \\
\text { German } \\
\text { prisons, } \\
\text { 1998- } \\
2001\end{array}$ & $\begin{array}{l}\text { Standard } \\
\text { interview } \\
\text { after } \\
4 \text { weeks in } \\
\text { prison, } 8 \\
\text { weeks in } \\
\text { prison, close } \\
\text { to release } \\
\text { (up to } 10 \\
\text { years) } \\
\text { Shame and } \\
\text { guilt: Emo- } \\
16 \text {-week } \\
\text { scale } \\
\text { Recidivism: } \\
\text { one or more } \\
\text { new } \\
\text { convictions } \\
\text { after release } \\
\text { (Federal } \\
\text { registry) }\end{array}$ & $\begin{array}{l}\text { At } 1^{\text {st }} \\
\text { interview - } \\
428 \text { (30\%) } \\
\text { never felt } \\
\text { guilt (no } \\
\text { guilt), } 859 \\
\text { (60\%) never } \\
\text { felt shame } \\
\text { At 2nd } \\
\text { interview- } \\
685 \text { (48\%) } \\
\text { no guilt, } 859 \\
\text { (63\%) no } \\
\text { shame } \\
\text { At } 3^{\text {rd }} \\
\text { interview - } \\
346 \text { (61\%) } \\
\text { no guilt, } 412 \\
\text { (72\%) no } \\
\text { shame } \\
\text { In Cox } \\
\text { hazard } \\
\text { models, } \\
\text { shame and } \\
\text { guilt at the } \\
\text { first } \\
\text { interview } \\
\text { each had a } \\
\text { small } \\
\text { significant } \\
\text { relationship } \\
\text { with } \\
\text { recidivism } \\
\text { ( } p<0.05 \text { ), } \\
\text { independen } \\
\text { tly of other } \\
\text { relevant } \\
\text { variables } \\
\text { (e.g. age) }\end{array}$ & \multirow[t]{2}{*}{$\begin{array}{l}\text { Feelings of } \\
\text { shame and } \\
\text { guilt } \\
\text { decreased } \\
\text { rapidly } \\
\text { during the } \\
\text { first weeks } \\
\text { of } \\
\text { imprisonme } \\
\text { nt and } \\
\text { continued } \\
\text { to decrease } \\
\text { during the } \\
\text { course of } \\
\text { imprisonme } \\
\text { nt } \\
\text { As } \\
\text { hypothesize } \\
\text { d, guilt } \\
\text { feelings are } \\
\text { associated } \\
\text { with lower } \\
\text { risk of } \\
\text { recidivism } \\
\text { but shame } \\
\text { with higher } \\
\text { risk of } \\
\text { recidivism }\end{array}$} & \multirow[t]{2}{*}{$\begin{array}{l}\text { No specific } \\
\text { guilt/sham } \\
\text { e-related } \\
\text { interventio } \\
\mathrm{n}\end{array}$} & \multirow[t]{2}{*}{$\begin{array}{l}\text { Hosser, } \\
\text { Windzio, } \\
\text { and } \\
\text { Greve } \\
(\underline{2008)}), \\
\text { Germany }\end{array}$} \\
\hline & & & $\begin{array}{l}54 \% \text { of } \\
\text { those with } \\
\text { guilt but no } \\
\text { shame and } \\
40 \% \text { with } \\
\text { shame but } \\
\text { no guilt had } \\
\text { no new } \\
\text { conviction }\end{array}$ & & & \\
\hline
\end{tabular}




\begin{tabular}{|c|c|c|c|c|c|c|}
\hline $\begin{array}{l}\text { Is guilt } \\
\text { about a } \\
\text { crime } \\
\text { related to } \\
\text { subsequent } \\
\text { offending? } \\
\text { Does } \\
\text { Aggression } \\
\text { Replaceme } \\
\text { nt Training } \\
\text { (ART) affect } \\
\text { this } \\
\text { relationship } \\
\text { ? }\end{array}$ & $\begin{array}{l}57 \text { young } \\
\text { male } \\
\text { offender } \\
\text { s (mean } \\
\text { age } 17 \\
\text { years, } \\
\text { range } \\
16-19 \text { ) } \\
\text { in one of } \\
\text { two } \\
\text { types of } \\
\text { residenti } \\
\text { al } \\
\text { setting, } \\
\text { with } \\
\text { different } \\
\text { treatme } \\
\text { nt } \\
\text { models }\end{array}$ & $\begin{array}{l}\text { Guilt - } \\
\text { Holmqvist } \\
\text { Affect } \\
\text { Consciousne } \\
\text { ss Interview } \\
\text { Reoffending } \\
\text { - national } \\
\text { sentence } \\
\text { and police } \\
\text { suspicion } \\
\text { registers, } \\
\text { applying } \\
\text { penalty } \\
\text { value scale }\end{array}$ & $\begin{array}{l}\text { Overall, } \\
\text { adolescents } \\
\text { who } \\
\text { admitted } \\
\text { their crimes } \\
\text { at intake or } \\
\text { who could } \\
\text { talk about } \\
\text { guilt for } \\
\text { their } \\
\text { criminal acts } \\
\text { were not } \\
\text { less likely to } \\
\text { be } \\
\text { recidivists } \\
\text { Adolescents } \\
\text { with less } \\
\text { initial } \\
\text { consciousne } \\
\text { ss of guilt } \\
\text { got better } \\
\text { results at } \\
\text { the ART } \\
\text { institutions }\end{array}$ & $\begin{array}{l}\text { A more } \\
\text { individualiz } \\
\text { ed } \\
\text { approach to } \\
\text { the use of } \\
\text { ART for } \\
\text { those } \\
\text { adolescents } \\
\text { who are } \\
\text { motivated } \\
\text { for it would } \\
\text { give better } \\
\text { results }\end{array}$ & $\begin{array}{l}\text { Very low- } \\
\text { powered } \\
\text { study }\end{array}$ & $\begin{array}{l}\text { Holmqvis } \\
\text { t, Hill, } \\
\text { and Lang } \\
\text { (2009), } \\
\text { Sweden }\end{array}$ \\
\hline
\end{tabular}

Three potentially relevant studies that failed inclusion criteria related remorse for an index offence to a history of recidivism prior to it (Corrado \& Peters, 2013; Golu \& Gorbănescu, 2014; Gorbănescu, 2013). Corrado and Peters (2013) evaluated remorse for an index offence with 447 incarcerated 12- to 19-year-olds, using a systematic seven-point Likert scale measure of remorse from Schneider (1990). They related it, however, to lifetime frequency of offending before the index incarceration, summarized as 'chronic offender' (more than four offences) or 'chronic serious offender' (more than four serious offences but including at least one serious offence). A summary of the results is worth mentioning, because they highlighted the importance of allowing for other risk factors for recidivism. Once such factors, like history of adverse events, had been taken into account, there was no relationship between remorse and chronic offending. There was, however, a tendency for a higher remorse score to be associated with a lower likelihood of being in the serous chronic offender group. The other two articles, from Romania, similarly measured remorse for an index offence, but related it to lifetime offending prior to the offence. They drew out guilt and shame distinctions, with their apparent relevance differing between the articles, although both studies were on imprisoned women.

\section{DISCUSSION}

It was to my great surprise that such references [to remorse] were scant, almost to the point of non-existence [in the standard forensic psychiatric texts of the time] ... all searches in specialist libraries, depending on appropriate databases, were only slightly more 
productive.... All the experts, representing the wide variety of disciplines included in this book, came up with much the same reply. (Cox, 1999, p. 15).

Little, it seems, has changed in the 20 years since Murray Cox wrote this. In spite of the weight accorded to the concept of remorse in court, and by humanity more generally, we found little evidence of empirical study of it. Even then, there were no reports in the literature relating directly to people with psychosis. Any reference to them in this context in the literature is related almost entirely to symptoms. A person with psychosis may believe, for example, that $s /$ he is an evil person or that they committed an unforgivable sin for which they must be punished (Kiran \& Chaudhury, 2009). Sometimes the guilt felt can be so intense that it can be displaced to parts of the body, commonly the face, genitalia and limbs, leading to self-mutilation(Ghaffari-Nejad, Kerdegari, \& Reihani-Kermani, 2007).

Furthermore, studies have shown that people with chronic psychotic symptoms have more interpersonal guilt feelings as compared with healthy controls and individuals with major depression (Britmann, Nasierowski, Murawiec, Pawlus, \& Fidler, 2012). Lake (2008) constructed an explanatory model of paranoid delusions, particularly but not exclusively in affective psychosis, that emerged in a pathway through delusions of guilt. All this amounts to a pathological acceptance of guilt or remorse without grounds, and not to feelings in relation to a real and terrible act committed, whether as a result of delusions or for more ordinary reasons.

It might be asked why people who kill in the context of not knowing what they were doing, or not knowing it was wrong for the believed circumstances, should or could feel any remorse while still suffering from the crucial delusion; and perhaps treatment of that psychotic symptom or state would be sufficient. Cox (1986), however, also described observing a sequencing of realization among people with psychosis who had killed, or come close to it, that seemed typical: "I didn't do it"; "I might have done it, but they made me do it"; "I did it, but was helpless". With something approaching illness recovery, this was followed by simple acceptance, "I did it", and finally the appropriate guilt coupled with personal responsibility, which is, perhaps, what constitutes remorse: "I did it and I don't want to do it again." Of interest, too, are Gudjonsson's findings that there is a correlation between mental attribution scores and acceptance of guilt (Gudjonsson, 1984; Gudjonsson \& Bownes, 1991; Gudjonsson \& Pétursson, 1991; Gudjonsson \& Singh, 1988). In other words, while blaming external factors for a crime reduces guilt feelings, blaming mental illness does not. Gudjonsson suggests that one possible explanation is that attributing an offence to the mental disorder is a form of internalising the attribution. Acceptance, for example, that had $\mathrm{s} /$ he been mentally well at the time of a homicide $\mathrm{s} /$ he would not have committed the offence may be an indicator of acceptance of the need for treatment, and improved safety through treatment.

Literature on psychopathy might be assumed to be relevant to our review - lack of remorse or guilt is one of the items in the 'selfish, callous and remorseless use of others' factor of the psychopathy checklist (Hare, 1991). This, however, refers to a scale designed to measure an enduring trait rather than a response to a specific event. It seems a less helpful concept than empathy here because of its circularity, which, put simply, says that people who do not experience remorse on numbers of occasions are remorseless. It is surely more useful to try 
to unpick more specific underlying characteristics that could then become a focus for treatment.

A capacity to recognize, feel and understand the state of mind of others by being able to imagine what they experience - including what another person is thinking and feeling - and to generate an appropriate response to those experiences seems an essential prerequisite to remorse. This ability to put oneself in the position of "the other" whilst remaining conscious of what belongs to oneself and what belongs to the other is referred to as empathy. Empathy might thus be a key capacity or trait as a prerequisite for remorse. There has been substantial interest in measuring it in schizophrenia, and studies have been consistent in finding generalized impairment in empathy among people with this disorder (Achim, Ouellet, Roy, \& Jackson, 2011; Bora, Yucel, \& Pantelis, 2009; Derntl et al., 2009; Haker, Schimansky, Jann, \& Rössler, 2012; Lee, Zaki, Harvey, Ochsner, \& Green, 2011; Montag, Heinz, Kunz, \& Gallinat, 2007; Smith, et al., 2015). Although there are no studies that relate this directly to homicide, there is evidence that, where empathy is impaired in schizophrenia, there is a higher risk of violence than where it is not. There are grounds for optimism that interventions may improve capacity, at least for components of empathy, e.g. emotion recognition (e.g. Wölwer et al., 2005), or more cognitive aspects of empathy, as in theory of mind (Roncone et al., 2004; Shamay-Tsoory et al., 2007). Furthermore, individuals with good recovery from schizophrenia have higher empathy scores than do those in remission (Chung et al., 2013).

\subsection{Expression of remorse and violent reoffending}

There is no more than a suggestion from the empirical literature that remorse is associated with future good behaviour, or the converse. That said, it is perhaps encouraging that the few findings do fit with the increasingly widely accepted model of separating components of guilt and shame, with the former having value for resolution and the latter being associated with avoidance (Tangney, Stuewig, \& Hafez, 2011) and possibly involving pathways through capacity for self-forgiveness associated with sense of guilt but not sense of shame (Griffin et al., 2016). Apart from a very few studies, once all other factors that increase risk of reoffending have been taken into account, any small relationship seems to be so attenuated as to suggest that remorse should not continue to hold its current standing. That said, there appears to have been no exploration of the role of remorse specific to homicide or other very serious violent offences, which might be different. For homicide, however, it is hard to be confident about the truthfulness of expressions of remorse in the course of the criminal justice process. On the one hand, in the UK at least, where a charge of murder is more likely than not after a homicide, legal advice is generally to plead not guilty, as the lesser offence of manslaughter cannot be considered otherwise. Given that acknowledgement of the offence is seen as a first step in remorse, the legal process itself may be undermining the opportunity to express genuine remorse. In homicide cases, too, there is very little opportunity for offender and even secondary victims to communicate with each other (Bibas \& Bierschbach, 2004), and yet remorse is an interactive process.

A life in prison does not encourage remorse, perhaps even diminishing it. For life-sentenced prisoners, it can be hard to survive, let alone admit remorse, in a system that is not designed to foster empathy (Nussbaum, 2016). We could find nothing specific on interventions with respect to remorse, guilt or shame in respect of homicide offenders specifically. There are some grounds for optimism that intervention programmes may help if correctly targeted (Holmqvist et al., 2009). In particular, an especially pertinent change - in victim empathy - 
may not only occur in itself, but also be associated with lower likelihood of recidivism among violent offenders (O'Brien \& Daffern, 2017).

\subsection{Limitations}

It is possible that our search terms and choice of literature databases failed to identify relevant literature, but they are transparent and presented here. Hand-searching a list of journals that included, at the least, remorse or relevant studies of experience of guilt for an act that had harmed others, and soft-searching through Google failed to add any new material. Even the studies we included, while relating to an index episode and subsequent offending, did not specify the nature of the offences.

\section{CONCLUSIONS}

There is little empirical evidence of any kind to support the weight placed on expression of remorse for any index offence in sentencing for that offence or in reviews of consequent detention, and none at all relating to a homicide or other serious violent offence by a person with schizophrenia. There is a small evidence base to suggest that this would be a fruitful area of study, relying on three main lines of research: first, that capacities or traits, principally empathy, relevant to being remorseful may be impaired among people with schizophrenia; second, that there may be some relationship between what might be construed as component parts of remorse - experience of guilt and/or shame for an offence or act - and reoffending; and third, that capacities or experience may be changed by treatment or other interventions and that relevant changes may, in turn, be associated with desistence from further offending. The literature is strong enough to suggest that research into valid measurement of remorse for a serious offence, associations of such measures with recidivism, and what interventions may work in which subgroups of offenders and in which circumstances to promote future safety would be warranted. It is not strong enough to support reliance on perceptions of remorse or its absence as a basis for sentencing and other judicial decisions.

\section{REFERENCES}

Achim, A. M., Ouellet, R., Roy, M. A., \& Jackson, P. L. (2011). Assessment of empathy in firstepisode psychosis and meta-analytic comparison with previous studies in schizophrenia. Psychiatry Research, 190(1), 3-8. https://doi.org/10. 1016/j.psychres.2010.10.030 Bandes, S. (2018). Remorse and demeanor in the courtroom: The cognitive science of evaluating contrition. In J. Hunter, P. Roberts, S. N. M. Young, \& D. Dixon (2018)(Eds.), The Integrity of Criminal Process: From Theory into Practice. Oxford, UK, In Press: Hart Publishing. Chapter also available at https://doi.org/10.2139/ssrn.2363326 Bibas, S., \& Bierschbach, R. A. (2004). Integrating remorse and apology into criminal procedure. Yale Law Journal, 114, 85. https://doi.org/10.2307/4135717 Bora, E., Yucel, M., \& Pantelis , C. (2009). Theory of mind impairment in schizophrenia: Meta-analysis. Schizophrenia Research, 109(1-3), 1-9. https://doi.org/10.1016/j.schres.2008.12.020 Bragado-Jiménez, M. D., \& Taylor, P. J. (2012). Schizophrenia, empathy and violence: Peer systematic review. Schizophrenia Research, 141,83-90. https://doi.org/10.1016/j.schres.2012.07.019 
Britmann, J., Nasierowski, T., Murawiec, S., Pawlus, M., \& Fidler, E. (2012). Intensification of interpersonal sense of guilt in patients with schizophrenia. Psychiatria Polska, 46(2), 157166. in Polish Chung, Y. C., Kim, H. M., Lee, K. H., Zhao, T., Huang, G. B., Park, T. W., \& Yang, J. C. (2013). Clinical characteristics of patients who have recovered from schizophrenia: the role of empathy and positive-self schema. Early Intervention in Psy-

chiatry, 7(2), 138-145. https://doi.org/10.1111/i.1751-7893.2012.00378.x Corrado, R. R., \& Peters, A. M. (2013). The relationship between a Schneider-based measure of remorse and chronic offending in a sample of incarcerated young offenders. Canadian Journal of Criminology and Criminal Justice, 55(1), 101-136. https://doi.org/10.3138/cjccj.2011.E.50 Cox, M. (1986). The "holding function" of dynamic psychotherapy in a custodial setting: Areview. Journal of the Royal Society of Medicine, 79, 162-164.

https://doi.org/10.1177/014107688607900310

Cox, M. (1999). Remorse and reparation. London, UK: Jessica Kingsley Publishers. Davis, J. R., \& Gold, G. J. (2011). An examination of emotional empathy, attributions of stability, and the link between perceived remorse and forgiveness. Personality and Individual Differences, 50(3), 392-397. https://doi.org/10.1016/i.paid. 2010.10.031

Derntl, B., Finkelmeyer, A., Toygar, T. K., Hülsmann, A., Schneider, F., Falkenberg, D. I., \& Habel, U. (2009). Generalized deficit in all core components of empathy in schizophrenia. Schizophrenia Research, 108(1-3), 197-206. https://doi.org/10. 1016/j.schres.2008.11.009 Derntl, B., Finkelmeyer, A., Voss, B., Eickhoff, S. B., Kellermann, T., Schneider, F., \& Habel, U. (2012). Neural correlates of the core facets of empathy in schizophrenia. Schizophrenia Research, 136(1-3), 70-81. https://doi.org/10.1016/i.schres. 2011.12.018

Eisenberg, T., Garvey, S. P., \& Wells, M. T. (1997). But was he sorry? The role of remorse in capital sentencing. Cornell Law Review, 83, 1599.

http://scholarship.law.cornell.edu/clr/vol83/iss6/5

Ghaffari-Nejad, A., Kerdegari, M., \& Reihani-Kermani, H. (2007). Self-mutilation of the nose in a schizophrenic patient with Cotard syndrome. Archives of Iranian Medicine, 10(4), $540-$ 542. 07104/AIM.0023

Gobodo-Madikizela, P. (2015). Psychological repair: The intersubjective dialogue of remorse and forgiveness in the aftermath of gross human rights violations. Journal of the American Psychoanalytic Association, 63(6), 1085-1123. https://doi.org/10.1177/0003065115615578 Golu, F., \& Gorbanescu, A. (2014). Applications of personal development in the re-education of imprisoned women.Procedia-Social and Behavioral Sciences, 127, 606-610.

https://doi.org/10.1016/j.sbspro.2014.03.320 Gorbanescu, A. (2013). Female Recidivism Prediction. Procedia-Social and Behavioral Sciences, 78, 46 5 0 . h t t p s : / / d o i . o r g / 1 0 . 1016/j.sbspro.2013.04.248 Griffin, B. J., Moloney, J. M., Green, J. D., Worthington, E. L., Cork, B., Tangney, J. P., ... Hook, J. N. (2016). Perpetratorsreactions to perceived interpersonal wrongdoing: The associations of guilt and shame with forgiving, punishing, andexcusing oneself. Self and Identity, 15(6), 650-661. https://doi.org/10.1080/15298868.2016.1187669

Gudjonsson, G. H. (1984). A new scale of interrogative suggestibility. Personality and Individual Differences, 5(3), 303-314.https://doi.org/10.1016/0191-8869(84)90069-2 Gudjonsson, G. H., \& Bownes, I. (1991). The attribution of blame and type of crime committed: Data for Northern Ireland.The Journal of Forensic Psychiatry, 2(3), 337-341. https://doi.org/10.1080/09585189108407668 
Gudjonsson, G. H., \& Pétursson, H. (1991). The attribution of blame and type of crime committed: Transcultural validation.Journal of the Forensic Science Society, 31(3), 349-352. https://doi.org/10.1016/s0015-7368(91)73167-8

Gudjonsson, G. H., \& Singh, K. K. (1988). Attribution of blame for criminal acts and its relationship with type of offence.Medicine, Science and the Law, 28(4), 301-303.

https://doi.org/10.1177/002580248802800407

Haker, H., Schimansky, J., Jann, S., \& Rössler, W. (2012). Self-reported empathic abilities in schizophrenia:a: Longitudinal perspective. Psychiatry Research, 200(2-3), 1028-1031. https://doi.org/10.1016/j.psychres.2012.04.004

Hare, R. D. (1991). The Hare psychopathy checklist-revised. North Tonawanda, NY: Multi Health Systems. Holmqvist, R., Hill, T., \& Lang, A. (2009). Effects of aggression replacement training in young offender institutions. International Journal of Offender Therapy and Comparative Criminology, 53(1), 74-92. https://doi.org/10.1177/0306624X07310452 Hosser, D., Windzio, M., \& Greve, W. (2008). Guilt and shame as predictors of recidivism: A longitudinal study with young prisoners. Criminal Justice and Behavior, 35(1), 138-152. https://doi.org/10.1177/0093854807309224

Jacobson, J., \& Hough, M. (2007). Mitigation: The role of personal factors in sentencing. http://www.prisonreformtrust.org. uk/uploads/documents/FINALFINALmitigation\%20\%20small.pdf Johansen, L. V. (2019). 'Impressed' by feelings-how judges perceive defendants' emotional expressions in danish courtrooms. Social \& Legal Studies, 28(2), 250269. https://doi.org/10.1177/0964663918764004

Jolliffe, D., \& Farrington, D. P. (2004). Empathy and offending: A systematic review and meta-analysis. Aggression and Violent Behavior, 9(5), 441-476.

https://doi.org/10.1016/j.avb.2003.03.001

Kiran, C., \& Chaudhury, S. (2009). Understanding delusions. Industrial Psychiatry Journal, 18(1), 3. https://doi.org/10.4103/0972-6748.57851

Lake, C. R. (2008). Hypothesis: Grandiosity and guilt cause paranoia: Paranoid schizophrenia is a psychotic mood disorder: A Review. Schizophrenia Bulletin, 34(6), 1151-1162.

https://doi.org/10.1093/schbul/sbm132

Lee, J., Zaki, J., Harvey, P. O., Ochsner, K., \& Green, M. F. (2011). Schizophrenia patients are impaired in empathic accuracy. Psychological Medicine, 41(11), 1-8.

https://doi.org/10.1017/S0033291711000614

Maslen, H. (2015). Remorse, penal theory and sentencing. Oxford, UK and Portland, USA: Hart Publishing (Bloomsbury). Montag, C., Heinz, A., Kunz, D., \& Gallinat, J. (2007). Selfreported empathic abilities in schizophrenia. Schizophrenia Research, 92(1-3), 85-89. https://doi.org/10.1016/j.schres.2007.01.024

Nussbaum, M. C. (2016). Anger and forgiveness: Resentment, generosity, justice. Oxford, UK: Oxford University Press. O'Brien, K., \& Daffern, M. (2017). Treatme nt gain in violent offenders: The relationship between proximal outcomes, risk reduction and violent recidivism. Psychiatry, Psychology and Law, 24(2), 244-258.

https://doi.org/10.1080/13218719. 2016.1209804

Padfield, N. (2013). Exploring the success of sentencing guidelines. In A. Ashworth, \& J. V. Roberts(Eds.), Sentencing Guidelines: Exploring the English Model. Oxford, UK: Oxford University Press.

Proeve, M., \& Tudor, S. (2010). Remorse: Psychological and jurisprudential perspectives. Farnham, UK: Ashgate. 
Roncone, R., Mazza, M., Frangou, I., De Risio, A., Ussorio, D., Tozzini, C., \& Casacchia, M. (2004). Rehabilitation of theory of mind deficit in schizophrenia: A pilot study of metacognitive strategies in group treatment. Neuropsychological Rehabilitation, 14, 421435. https://doi.org/10.1080/09602010343000291

Schneider, A. L. (1990). Deterrence and Juvenile Crime: Results from a National Policy Experiment. New York: Springer-Verlag. Shamay-Tsoory, S. G., Shur, S., Barcai-Goodman, L., Medlovich, S., Harari, H., \& Levkovitz, Y. (2007). Dissociation of cognitive from affective components of theory of mind in schizophrenia. Psychiatry Research, 149(1-3), 11-23. https://doi.org/10.1016/j.psychres.2005.10.018

Smith, M. J., Schroeder, M. P., Abram, S. V., Goldman, M. B., Parrish, T. B., Wang, X., ... Breiter, H. C. (2015). Alterations inbrain activation during cognitive empathy are related to social functioning in schizophrenia. Schizophrenia Bulletin, 41(1),

211-222. https://doi.org/10.1093/schbul/sbu023

Tangney, J. P., Stuewig, J., \& Hafez, L. (2011). Shame, guilt, and remorse: Implications for offender populations. Journal of Forensic Psychiatry \& Psychology , 22(5), 706-723.

https://doi.org/10.1090/14789949.2011.617541

Tilghman-Osborne, C., Cole, D. A., \& Felton, J. W. (2010). Definition and measurement of guilt: Implications for clinical research and practice. Clinical Psychology Review, 30(5), 536546. https://doi.org/10.1016/j.cpr.2010.03.007

van Oorschot, I., Mascini, P., \& Weenink, D. (2017). Remorse in context (s): A qualitative exploration of the negotiation of remorse and its consequences. Social \& Legal Studies, 26(3), 359-377. https://doi.org/10.1177/ 0964663916679039 Wölwer, W., Frommann, N., Halfmann, S., Piaszek, A., Streit, M., \& Gaebel, W. (2005). Remediation of impairments in facial affect recognition in schizophrenia: Efficacy and specificity of a new training program. Schizophrenia Research, 80(2-3), 295-303. https://doi.org/10.1016/j.schres.2005.07.018 Zhong, R. (2015). Judging Remorse. New York University Review of law \& Social Change, 39, 133. https://socialchangenyu. com/review/judging-remorse/

Zhong, R., Baranoski, M., Feigenson, N., Davidson, L., Buchanan, A., \& Zonana, H. (2014). So you're sorry? The role of remorse in criminal law. Journal of the American Academy of Psychiatry and the Law, 